\title{
Towards Sustainable Buildings in Bahrain, Kuwait and United Arab Emirates
}

\author{
N. W. Alnaser* \\ School of Construction Management, University of Reading, UK
}

\begin{abstract}
In this paper we had highlighted on the current sustainable building in Bahrain, United Arab Emirate and Kuwait. Some of these buildings are integrated with wind turbines, i.e. Bahrain World Trade Centre, Bahrain , with Photovoltaic, i.e. The Euro-University, Bahrain, and The English School, Kuwait, and combination of both ( wind turbine and Photovoltaic), i.e. The Lighthouse, Dubai, UAE. There is also a building that is sustainable due to its unique cooling and innovative design, i.e. the MKM Commercial Holdings LLC, Dubai, and UAE. We also had discussed the hurdles of constructing sustainable buildings in these three countries and the GCC countries. We also had suggested several mechanisms and policies that will accelerate the execution of sustainable buildings.
\end{abstract}

\section{INTRODUCTION}

There are many indicators for sustainable building design. Among these [1]; a) Identifying opportunities to generate on-site renewable electricity, i.e. like Building Integrating Photovoltaic (BIPV), b) Minimizing the use of fossilbased energy in terms of energy embodied in the material, transport and construction process and energy used during the lifetime of the building, c) Ensuring that building management systems are user friendly and not over-complex ,d) Making best use of passive(or active) solar energy while employing heating /cooling systems which are fine-tuned to the needs of the occupants with air conditioning used only in exceptional circumstances.

Among the guidance for the design of government policies to address the environmental issues related to sustainable building is reducing of $\mathrm{CO}_{2}$ emission, minimizing of construction and demolition waste, and prevention of indoor air pollution [2]. The first installation of building-integrated photovoltaic (BIPV) - which is one type of sustainable building - was realized in 1991 in Aachen, Germany [3]. The photovoltaic elements were integrated into a curtain wall façade with isolating glass. Meanwhile, the first world large scale Building Integrated Wind Turbine (BIWT) is in Bahrain, i.e. The World Bahrain Trade Centre (to be in operation in late 2007 or early 2008).

Today, photovoltaic modules for building integration are produced as a standard building product- fitting into standard façade and roof structures. These elements created a whole new market and since then building integration is one of the fastest growing market segments in photovoltaic. An impressive solar installation is the Academy Mont-Cenis in Herne (Germany)- with more than $10000 \mathrm{~m}^{2}$ of photovoltaic integrated into the roof and façade-and was completed in March 2001. Several other large-scale projects, worldwide, are under construction or in the planning phase [3].

*Address correspondence to this author at the School of Construction Management, University of Reading, UK; Tel: 00447894524919/0097339 474000; Fax: 0097317827766; E-mail: naser1301 @ gmail.com
In countries like Bahrain and UAE, people spend more than 90 percent of their time indoors. Therefore, green buildings or sustainable buildings offer healthier and more efficient solutions to owners, occupants and businesses. It has been demonstrated that energy and water efficient buildings have been able to reduce the operating costs by more than 50 percent by employing well-integrated green design concept.

Green buildings are environmentally responsible structures that are based on a practical and simple approach in their design and construction. For instance, they optimize the use of interior spaces so that the overall building size and use of resources in constructing and operating them are kept to a minimum. Other factors such as sustainability, energy efficiency, water conservation, indoor air quality, and the use of non-toxic, eco-friendly materials within the structure is also important. A green building is about logical steps to reduce impact on the environment, some of which are very simple. As a small example, we reduced the number of lights installed in the building by maximizing the use of indirect sunlight, thus reducing costs while still ensuring each person was receiving appropriate illumination for his job. What we learnt in the process was that green buildings have a significant economic advantage. Contrary to popular belief that taking care of the environment is a costly affair, some experiences show that was possible to reduce both capital and operating costs by becoming a green building. Green building incorporates excellent practice that result in environment protection, water conservation, energy efficiency, usage of recycled products and renewable energy. The Typical Features of a Green Building includes: Sustainable Sites, Water Quality and Efficiency, Energy and Atmosphere, Materials and Resources, Indoor Environmental Quality (IEQ) and Innovative Design.

Green Buildings also provide many advantages. These are: Marketability value, Energy efficiency performance, Less emissions, Adequate day lighting \& good distribution, Less glare, Low energy and water consumptions, Better ventilation, Free from high VOCs, Indoor Air Quality, Free from Sick-building Syndromes, Better healthy conditions, Less absenteeism, Higher productivity, Better schools high exams' results, Long lifecycle, and Benefits from Green Buildings. 
A Green Building has 7 proven added values [4,5]:

a) Reducing building-related illness;

b) Improving health conditions;

c) Decreasing absenteeism by $15 \%$ if compared with conventional buildings;

d) Increasing occupants productivity;

e) Improving pupils performance and results;

f) Prolonging building's lifecycle

Nowadays, many large buildings in Bahrain and United Arab Emirates - and in the region- are built without any considerations for sustainability from all stakeholders (client and policy makers), i.e. designing and constructing buildings with glass cladding and big openings which could create energy crisis and damage to the environment (emission of $\mathrm{CO}_{2}$ ). However, recently few major building projects are of sustainable types. This paper will highlight and discuss these projects.

\section{THE SUSTAINABLE BUILDINGS IN BAHRAIN, UAE AND KUWAIT}

\section{Bahrain World trade Centre (A sustainable Building- First World Building Integrated Wind turbine).}

Fast nearing completion in the heart of the city, the Bahrain World Trade Centre boasts innovative features such as wind turbines to generate electricity, intelligent building technology and high fire safety standards, which make it a highly interesting construction project on a global scale.

The Bahrain World Trade Centre site is in a prestigious location on the main King Faisal Highway in Manama, Bahrain. The site, offering unobstructed views over the Arabian Gulf, is currently developed over half its area and comprises the Bahrain Sheraton Hotel, the associated single-storey luxury shopping mall, an office tower, car parking, services and landscaped areas. The design of the new development will provide additional twin office towers, a new shopping mall with anchor tenant, garden court and food outlets. Overall, the entire site will include improvements which are intended to rejuvenate and breathe new life to the existing mall and hotel development [6].

Two triangular shaped towers taper to a height of $240 \mathrm{~m}$ in an elegant juxtaposition. Harmoniously reflecting each other, the towers are located above a sculpted three-storey podium and basement. Each tower provides 34 floors of office space (including upper level duplexes) and an exclusive viewing deck on the 42 nd floor. The podium accommodates a single-storey extension to the existing shopping mall together with three levels of covered car parking. Further extensive parking and service area are provided in the basement.

The twin, triangular-shaped $240 \mathrm{~m}$ high towers are intended to serve as a timeless icon for the Kingdom of Bahrain. The towers are arranged on either side of the central axis of the development with the dividing spacing between them crucial to their composition and in helping to achieve a fine dialogue, whilst still projecting a harmonious and unified image. Borrowing from the theme offered by its prominent location, the various elements of the design form have a distinctly nautical flavour. Each tower is visually anchored to the ground by a concertina of curved; sail-like forms that progressively peel back to reveal a dramatic form that resembles a shard of blue glass. The sail-shaped towers will not only embody Bahrain's maritime past but the project will also surpass existing boundaries of construction technology by becoming the world's first to suspend electricitygenerating wind turbines between two commercial tower structures.

BWTC was Designed and engineered by WS Atkins, the Bahrain WTC incorporates pioneering architecture, comprising of two stunning sail-shaped towers complete with three turbines connecting the two commercial towers.

The towers and turbines were inspired by traditional Arabian wind towers which harness the wind energy from the onshore breeze that is now transformed into a 21 st century form and building typology, wind power is expected to produce a sizeable portion of the building's power requirements. The project will serve as a model for an environmentally-conscious design and help pave the way for future projects to also integrate energy from wind power.

The maritime theme is echoed not only in the shape of the towers but also in the exterior façade elements, which resemble nautical features such as the sails of a ship. The interiors of the mall and office areas, being designed by international interior designer (Aedas), replicate the wind turbine theme with their blade-inspired décor. Fountains and water features enhance the overall ambiance of both the interior and exterior areas. The tower facades will primarily consist of a unitised cladding and curtain walling system, which is manufactured incorporating aluminum, glass and insulation as a complete module in an air-conditioned factory to ensure the highest quality of the final product. The façade treatment to the podium and the existing mall will consist of a combination of stone cladding and a stick system of curtain walling and aluminum cladding.

The towers rise above a three-storey sculpted podium and basement on a trapezoidal site on King Faisal Highway and enjoy unobstructed views over the Arabian Gulf along the entire $340 \mathrm{~m}$ northwestern frontage.

\section{The Three Parallel wind Turbines in BWTC}

The three wind turbines will be installed on 65-tonne bridges, which are currently being manufactured. Conventional bridge bearings including single-point bearings and rolling bearings transfer the load of the bridges to the building structure. Each turbine spans $29 \mathrm{~m}$ in diameter and will generate between 1,100 and 1,300 MWh per year, which will amount to approximately 11 to 15 per cent of the office tower's electrical energy consumption. In carbon emission terms this equates to an average of $55,000 \mathrm{~kg}$ of $\mathrm{CO}_{2}$ (UK electricity basis). The first turbine (among the three) was erected in 15 March 2007. The frequency response of the bridges, turbines and blades has been taken into account in the design to mitigate transmission of noise and vibration to the building. The speed of the blades has been lowered to an optimum level compared to standard wind turbines. In addition, the sound insulation of the cladding adjacent to the line of the blades has been beefed up and the thickness of the glass near the wind turbines has also been increased (Figs. 1 \& 2). 


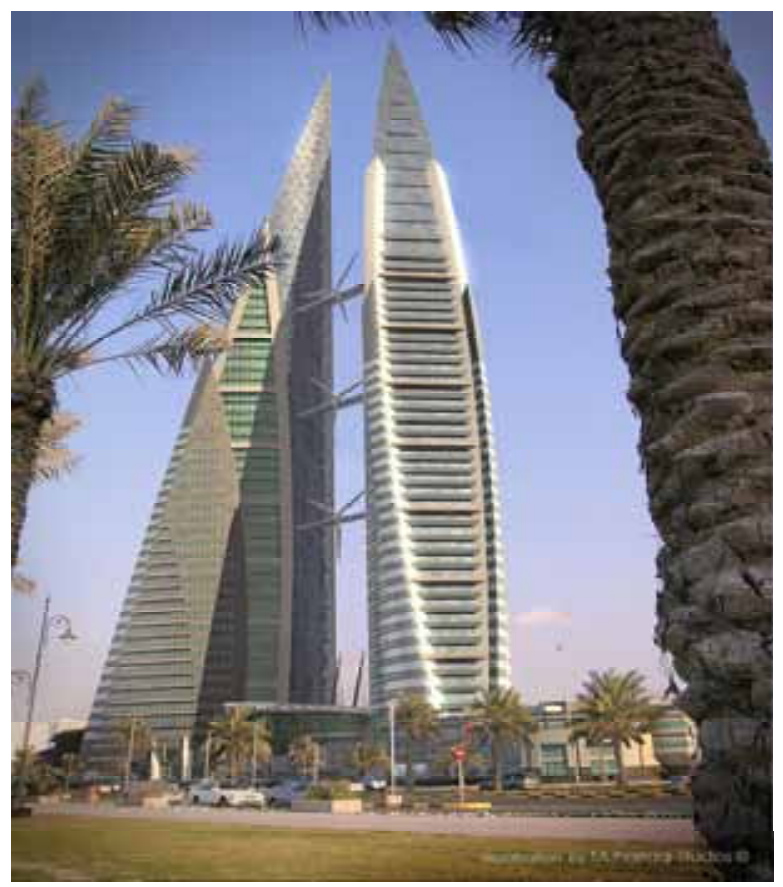

Fig. (1). The three parallel wind turbines are able to generate between 1100 and 1300 MWh per year, which will amount to approximately 11 to 15 per cent of the office tower's electrical energy consumption.

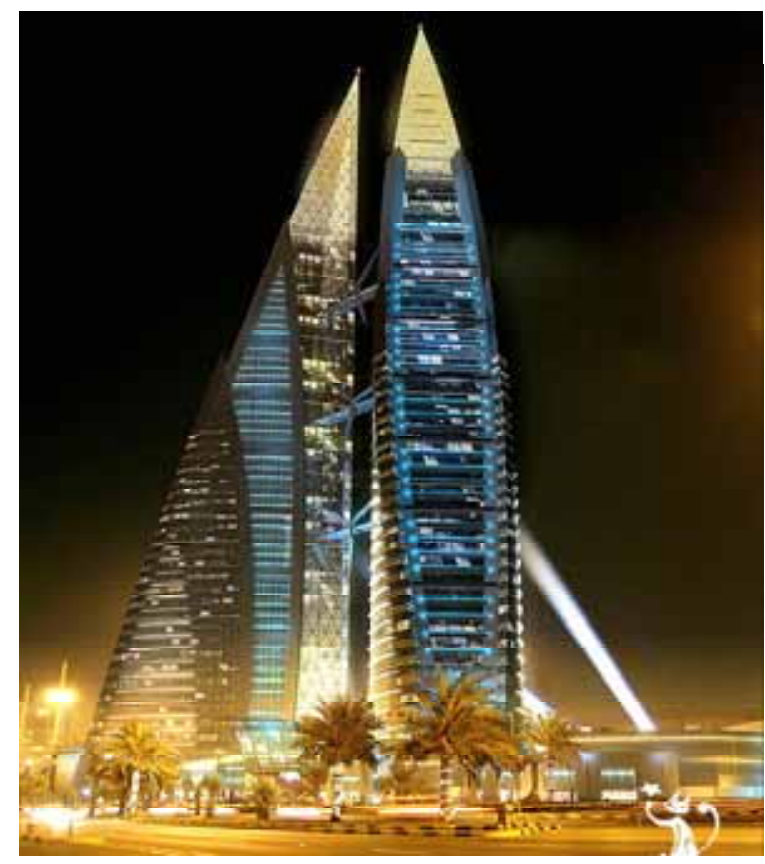

Fig. (2). The three parallel wind turbines are able to reduce the carbon emission terms this equates to an average of $55,000 \mathrm{~kg}$ of $\mathrm{CO}_{2}$ (UK electricity basis).

\section{Environmentally Responsive Design of BWTC}

This building is not intended to be a low carbon emission solution by European and otherworld-wide standards. However, aside from the wind turbines, it does include a number of other design features that are of interest and reduce carbon emissions when compared to other buildings in the Middle East. These are summarised below [6]:

- Buffer spaces between the external environment and air conditioned spaces -examples include a car park deck above and to the southern side of the mall which will have the effect of reducing sol air temperature and reducing conductive solar gain.

- Deep gravel roofs in some locations that provide kinetic insulation;

- Significant proportion of projectile shading to external glass facades. Balconies to the sloping elevations with overhangs to provide shading where shading is not provided to glazing, a high quality solar glass is used with.

- low shading co-efficient to minimise solar gains.

- Low leakage, openable windows to allow mixed mode operation in winter

Months.

- Enhanced thermal insulation for opaque fabric elements.

- Dense concrete core and floor slabs presented to the internal environment in a manner that will level loads and reduce peak demand with associated reductions in air and chilled water transport systems.

- Variable volume chilled water pumping that will operate with significantly less pump power at part loads than conventional constant volume pumping.

- Low pressure loss distribution for primary air and water transport systems that reduces fan and pump power requirements.

- Total heat energy recovery heat wheels of fresh air intake and exhausts to recover "coolth" from the vitiated air and recover it to the fresh make up air.

- Energy efficient, high efficacy, high frequency fluorescent lighting with zonal control.

- Dual drainage systems that segregate foul and waste water and allow grey water recycling to be added at a later date.

- Connection to the district cooling system that will allow an order of magnitude improvement on carbon emissions since in Bahrain efficient water cooled chiller are not allowed due to water shortage, whereas the district cooling solution will involve sea water cooling / heat rejection and much improved levels of energy conversion efficiency.

- Dual flush WC and electronic taps with excess water flow restrictors;

- Reflection pools at building entrances to provide local evaporative cooling;

- Extensive landscaping to reduce site albedo (ratio of reflected solar radiation to the incident one), generate $\mathrm{CO}_{2}$ and provide shading to on grade car parks;

- Solar powered road and amenity lighting. 


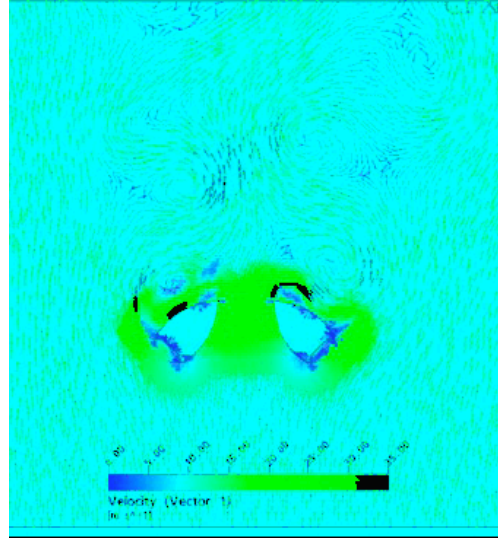

Wind direction $315^{\circ}$ (simulation $90^{\circ}$ )

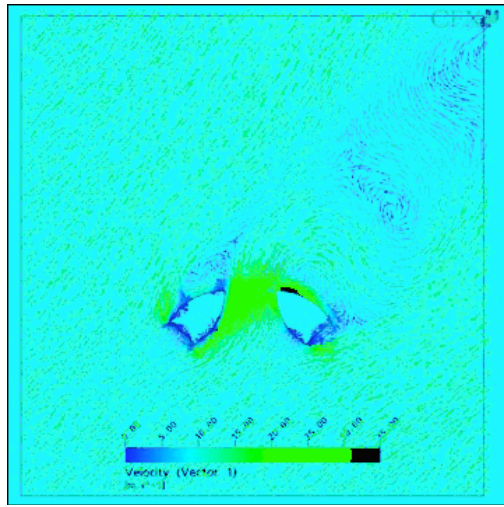

Wind direction $360^{\circ}$ ( simulation $45^{\circ}$ )

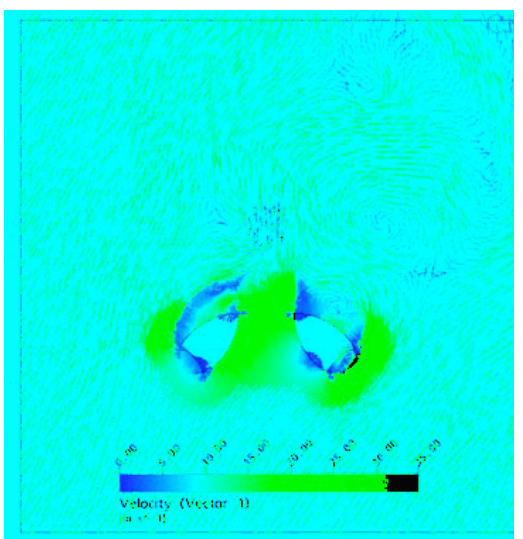

Wind direction $345^{\circ}$ ( simulation $60^{\circ}$ )

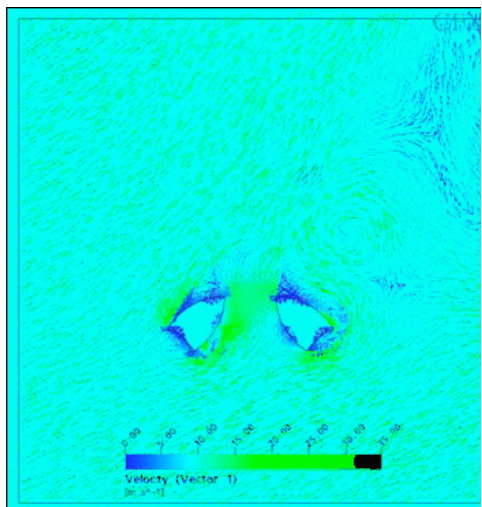

Wind direction $15^{\circ}\left(\right.$ simulation $\left.30^{\circ}\right)$

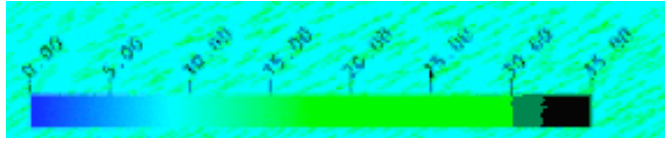

Fig. (3). CFD Images by Ramboll showing airflow patterns near towers, simulated at the level of the top turbine for different free, undisturbed wind incidence angles with respect to an ' $x$ ' axis (i.e. horizontal line connecting towers) [6]. The wind velocity is in $\mathrm{m} / \mathrm{s}$.

Engineering predictions show that the turbine will be able to operate for wind directions between $270^{\circ}$ and $360^{\circ}$ (Fig. 3), however, caution has been applied and turbine predictions and initial operating regimes are based a more limited range of between $285^{\circ}$ and $345^{\circ}$. At all wind directions outside of this range the turbine will automatically adopt a

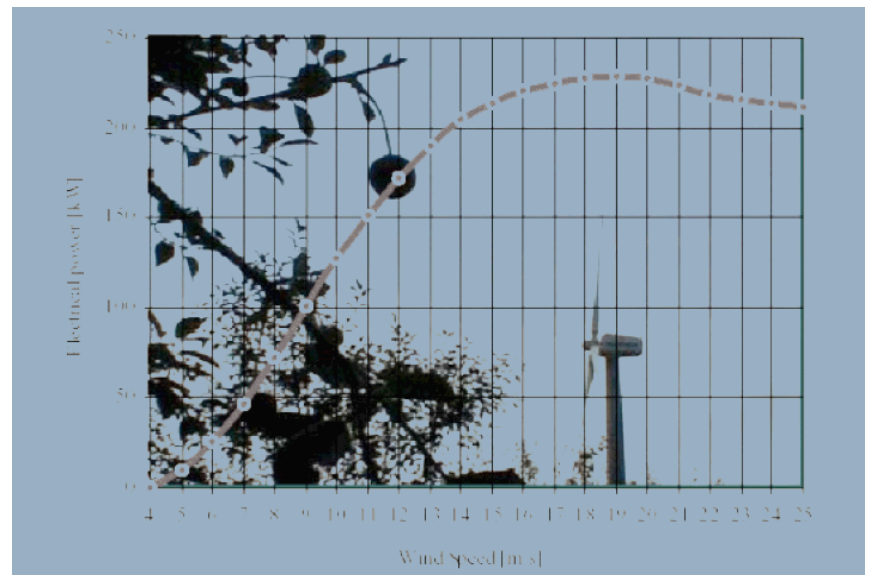

Fig. (4). Electrical Power versus wind speed. "standstill" mode. It is no coincidence that the buildings are orientated to the extremely dominant prevailing wind.

The funneling of the towers has the effect of amplifying the wind speed at the turbine location of up to $30 \%$. This amplification, in conjunction with the shape of the towers (larger effect at ground) and the velocity profile of the wind (lowest at ground) has the effect of balancing the energy yield to the extent that the upper and lower turbines will produce $109 \%$ and $93 \%$ when compared to $100 \%$ for the middle turbine. The full power of about $225 \mathrm{~kW}$ will be achieved at 15 to $20 \mathrm{~m} / \mathrm{s}$ (Fig. 4.) depending on air density. In the event of extremely high wind speeds under operating or standstill modes, the tip of the blade extends by centrifugal force and rotates to act as a self regulating governor brake, through the exertion of a drag force.

The bridges are ovoid in section for aerodynamic purposes and are relatively complex structures because they incorporate maintenance free bearings where they connect to the buildings to allow the towers to move $0.5 \mathrm{~m}$ relative to each other. In addition, the bridges that span $31.7 \mathrm{~m}$ and support a nacelle with a mass of 11 tonnes have been designed to withstand and absorb wind induced vibration and vibrations induced by both an operating and "standstill" turbine. 


\section{Control, Monitoring and Safety}

Turbine control, monitoring and safety is delivered through three systems:

- Wind turbine control system (WTCS) that directly controls and monitors the turbines;

- Extended wind turbine monitoring system (EWTMS) that is a separate monitoring system developed for this project;

- Building monitoring system (BMS).

The WTCS is an industrial quality control system that has been specifically evolved to control and monitor wind turbines. It is robust and reliable and as well its control and monitoring functions, it is able to shutdown turbines safely in the event of adverse climatic conditions or due to other factors that will threaten life-safety or turbine life. It is an on-line system that allows operators anywhere to gain access to the operating data and grant those with appropriate authorization control of the turbines. It has an in-built independent, emergency, safety surveillance system that will monitor possible faults in the turbine and the immediate turbine operating environment and bring it to a standstill, if required. This system overrides the electronic control system.

\section{Energy Analysis}

The projected energy yield from the turbines taking into account wind and availability data is summarized in Table $\mathbf{1}$. This amounts to between 1,100 and 1,300 MWh per year and will amount to approximately $11 \%$ to $15 \%$ of the office tower's electrical energy consumption. In carbon emission terms this equates to an average of $2900 \mathrm{~kg} \mathrm{CO}_{2}$ (oil burning power station) or $2000 \mathrm{~kg} \mathrm{CO}_{2}$ (gas burning power station). These figures are conservative. Since this is a world first and because wind turbines have not been placed $160 \mathrm{~m}$ above ground level and between buildings, the yield may even be higher.

\section{Challenges}

Given the limited number of skyscrapers that have been constructed in Bahrain, the project has provided a learning curve for all parties involved in the project. The first chal-
Table 1. Energy yield from the three parallel wind turbines at different heights (nearly $60 \mathrm{~m}, 120 \mathrm{~m}$ and $180 \mathrm{~m}$ ) in Bahrain World Trade Centre BWTC Building

\begin{tabular}{|l|l|}
\hline Turbine \# 1 & 340 to $400 \mathrm{MWh} /$ year \\
\hline Turbine \# 2 & 360 to $430 \mathrm{MWh} /$ year \\
\hline Turbine \# 3 & 400 to $470 \mathrm{MWh} /$ year \\
\hline
\end{tabular}

lenge encountered on the project was appointing a contractor through competitive tendering. BWTC management wanted to launch the work immediately but had only the concept drawings to proceed with. So they went ahead on a remeasurable contract and managed to get a good value for the client. By this method they were able to save around 10 to 12 months. They had to start a month before the preliminary design review came out in July (2004). The biggest challenge was in designing and constructing the building in parallel.

\section{The Euro University - Green City (A Sustainable Building; the First Large BIPV in the Middle East)}

Bahrain is to build the first Green City in the Middle East, at a cost of more than BD 80 million. This was revealed in 2005. Several international consultants are bidding for the project which will be located in A'ali town, at the site of the new Euro University.

The University will house students and staff from the university, but will serve as a model for environmentallyfriendly development. The city is also expected to draw international environmental research and consultancy companies. The project is the brainchild of Southern Governor and Public Commission for the Protection of Marine Resources; Environment and Wildlife head Shaikh Abdulla bin Hamad Al Khalifa, who is also the Euro University honorary president. Designs suppose to be completed in 2006 and the city will be fully developed in the next five years. Euro University will be one of the tenants of the Green City, which will be environmentally designed and ecologically oriented. The Green City will have its own desalination and power plants

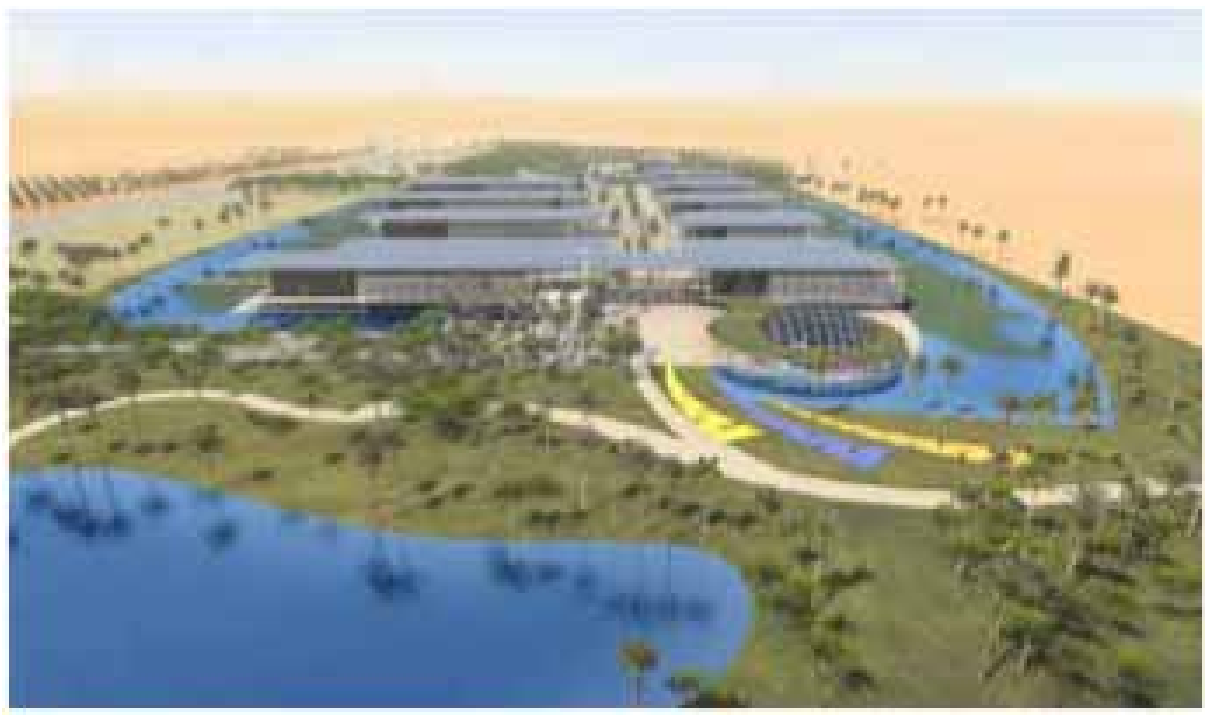

Fig. (5). A master plan of the Euro University showing the major PV covered area. 
using solar energy, waste water treatment plant, and sewerage system based on pressurized air and suction. The TechnoloGreen City would also be equipped with state-of-the-art air quality monitoring system which would produce reports on the quality of air in Bahrain every 30 minutes.

The Green City is a project for Bahrain's next generation and it will be a reference platform for people in the region who seek a solution to their environmental problems (Figs. 5 $-7)$.

3. MKM COMMERCIAL HOLDINGS LLC, DUBAI, UAE

The MKM Commercial Holdings LLC for the 1st LEED Silver Rated Green Building (June 6, 2006). MKM Com- mercial Holdings LLC commissioned the professional services of Green Technologies FZCO to lead this project and deliver a fully operational District Cooling Plant (Fig. 8).

The construction of the Wafi City commenced in 1989 and over the past sixteen years has developed into a 125,000 square meter commercial and residential development. Construction of the Wafi City development has taken place in five distinct phases resulting in five chilled water generating stations being constructed to serve each phase of the development. The total installed chilled water plant capacity in 2005 was $18300 \mathrm{~kW}$ (5200 Tons of BTU).

The District Cooling Chilled Water Plant will have 16,000 Tons of cooling generated by one of the most energy

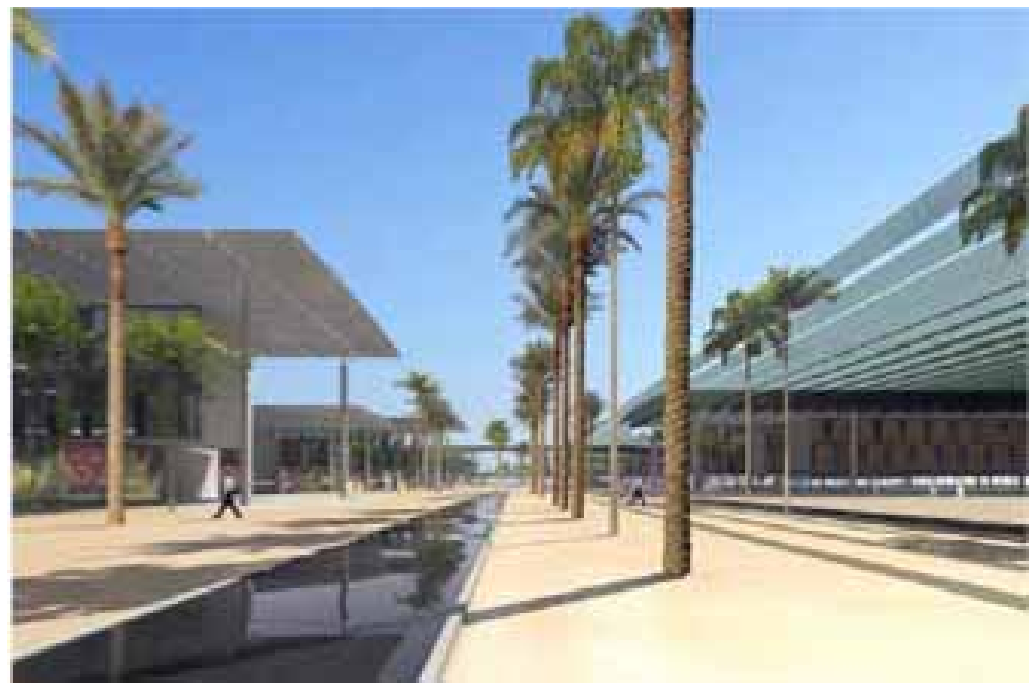

Fig. (6). A walk way at Euro University showing major PV covered area providing shade and producing electricity.

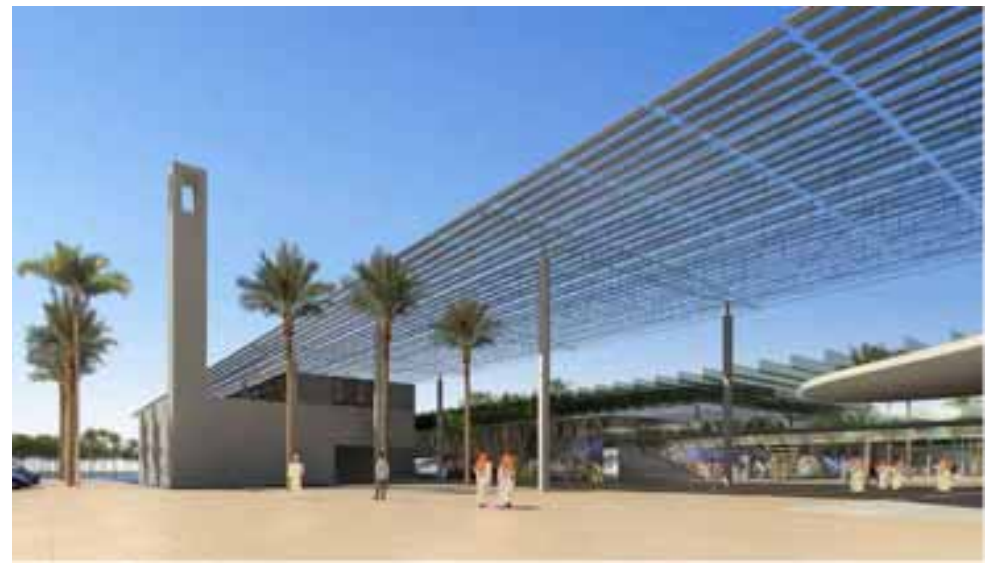

Fig. (7). Another walk way at Euro university showing major PV covered area providing shade and producing electricity.

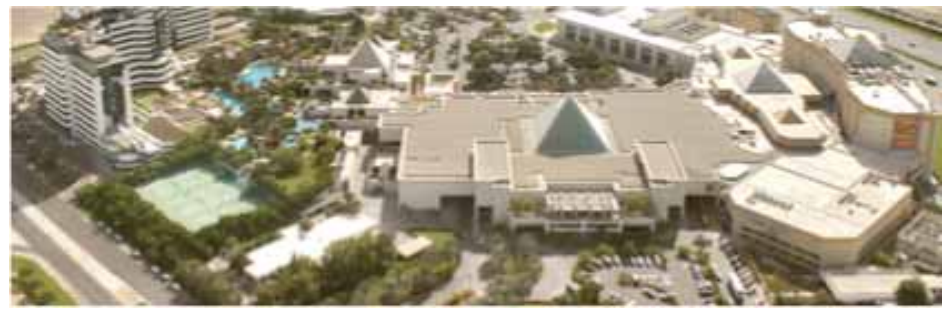

Fig. (8). The Wafi City District Cooling Chiller Plant DCCP ONE. 


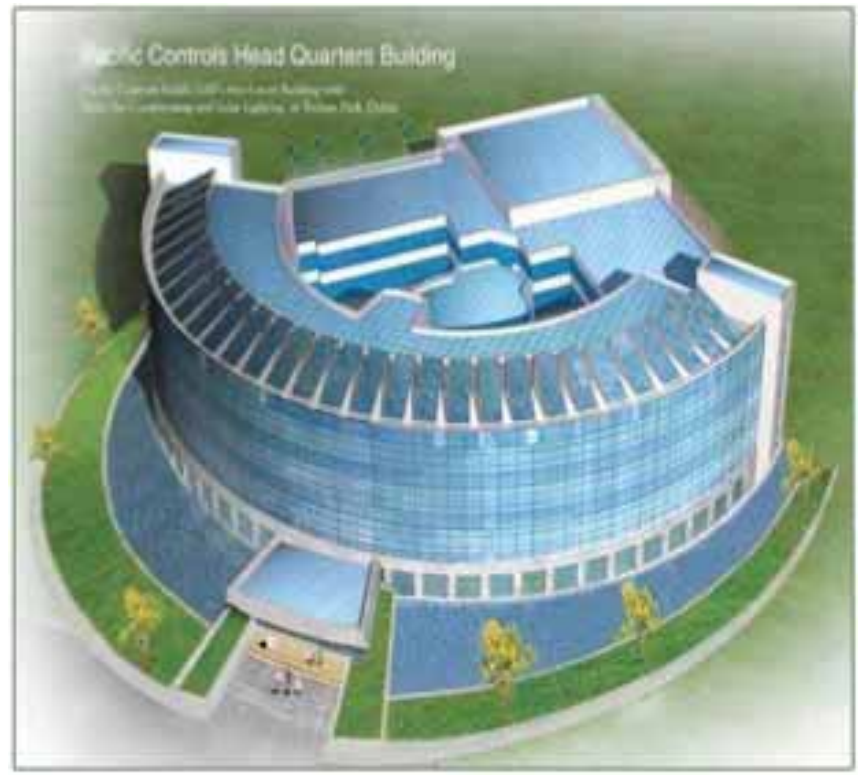

Fig. (9). The 1st LEED Platinum rated Green Building in the UAE. Pacific Controls Headquarters in Techno land, Dubai. The Building uses thermally Efficient roofs, walls \& windows, HVAC systems \& efficient electrical lighting strategies that capitalize on daylight and HVAC system incorporating solar air-conditioning using absorption chillers.

and water efficient Chiller Plant Systems to be installed in the region. The first phase of the project was completed in the winter of 2006, with the final phase due for completion by the winter 2008 .

\section{MKM COMMERCIAL HOLDINGS LLC, DUBAI, UAE (THE LEED PLATINUM RATED "GREEN BUILDING" AT THE TECHNO PARK, DUBAI)}

The Pacific Control Systems for the 1st LEED Platinum Rated Green Building (June 28, 2006). The building of the Pacific Control Systems is one of the 16 buildings across the world to make that grade, which explains why it is a matter

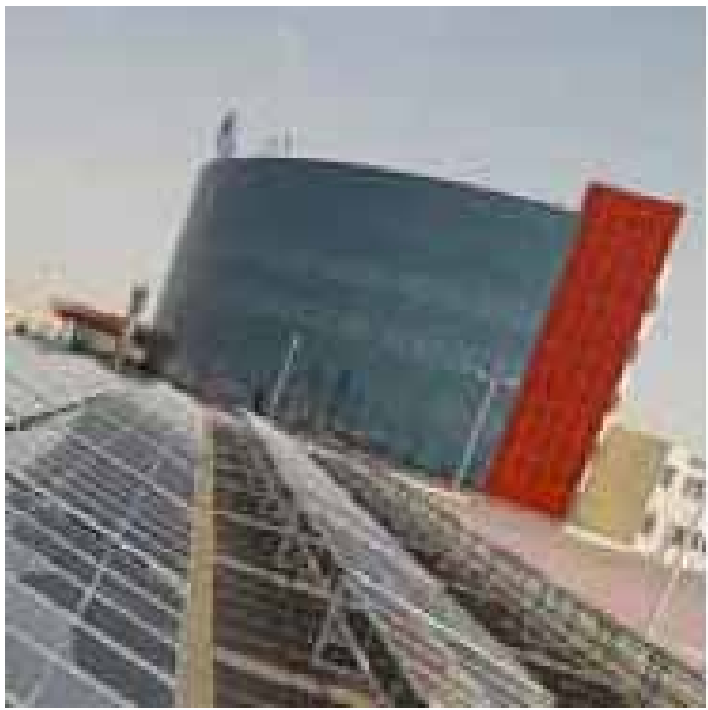

of pride not just for the company but also the UAE (Fig. 9). Opened on 1st September 2006, the facility houses Pacific Controls Headquarters, U-City Development Centre, R \& D Centre for M2M Technologies, Energy Performance, Industrial \& Commercial Automation, U-home Products and Solutions. The facility also houses $24 \times 7 \times 365$ Global Command Control Centre, Product Engineering and Development Facility and has capacity for 600 employees.

Fig. 9: The 1st LEED Platinum rated Green Building in the UAE. Pacific Controls Headquarters in Techno land, Dubai. The Building uses thermally Efficient roofs, walls \& windows, HVAC systems \& efficient electrical lighting strategies that capitalize on daylight and HVAC system incorporating solar air-conditioning using absorption chillers.

The Pacific Controls green building functions on a totally integrated IP enabled Automation System integrating the services in the building including the BMS, IP Telephony, Lighting Controls, AV Systems, Solar PV Air-conditioning \& Lighting., Fire Alarm, Lift Alarm, Access Control, IP cameras, Solar Thermal Air-conditioning System, STP, etc, which makes this building totally transparent in terms of its engineering services. This helps to maintain system reliability while substantially reducing operating and maintenance costs and increasing service efficiency.

The Pacific Control Systems building (Fig. 10) has 100 per cent of water at the building will be recycled and used for landscaping. The roof of the building has photovoltaic cells (which provide solar power, BIPV) that will supply lighting during the day while solar air-conditioning will also be used to satisfy 25 per cent of the building's 400-tonne cooling requirement. Materials used for its construction were sourced from within $200 \mathrm{~km}$ of Dubai. This was done to boost the local economy and reduce unnecessary pollution during the transportation of these materials. Bonding materials were also used to curb land erosion. Construction waste was segregated and disposed on green guidelines.

The building has waterless urinals in some areas. Recycled wood and eco-friendly sealants, paints and carpets were incorporated into the interiors. Carbon dioxide sensors were

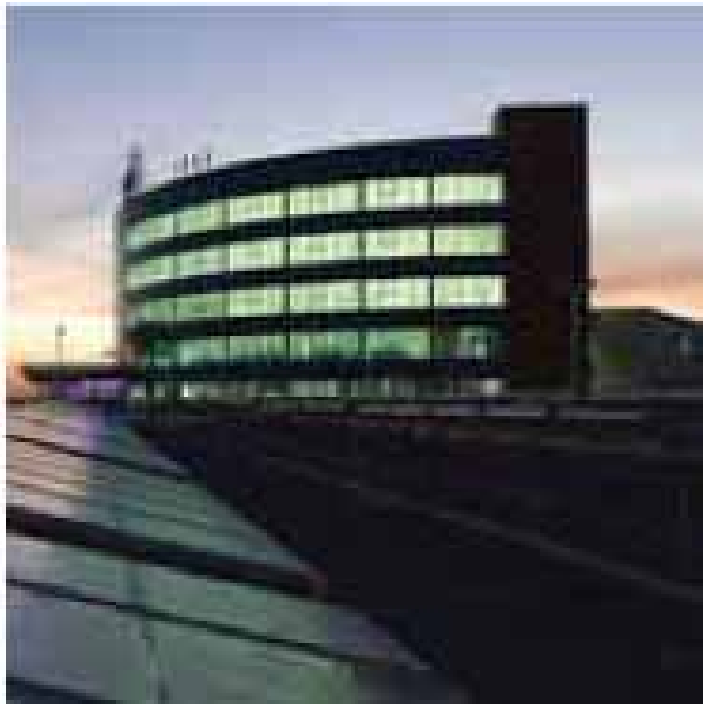

Fig. (10). Some images of the Pacific Control Systems building in Dubai. 


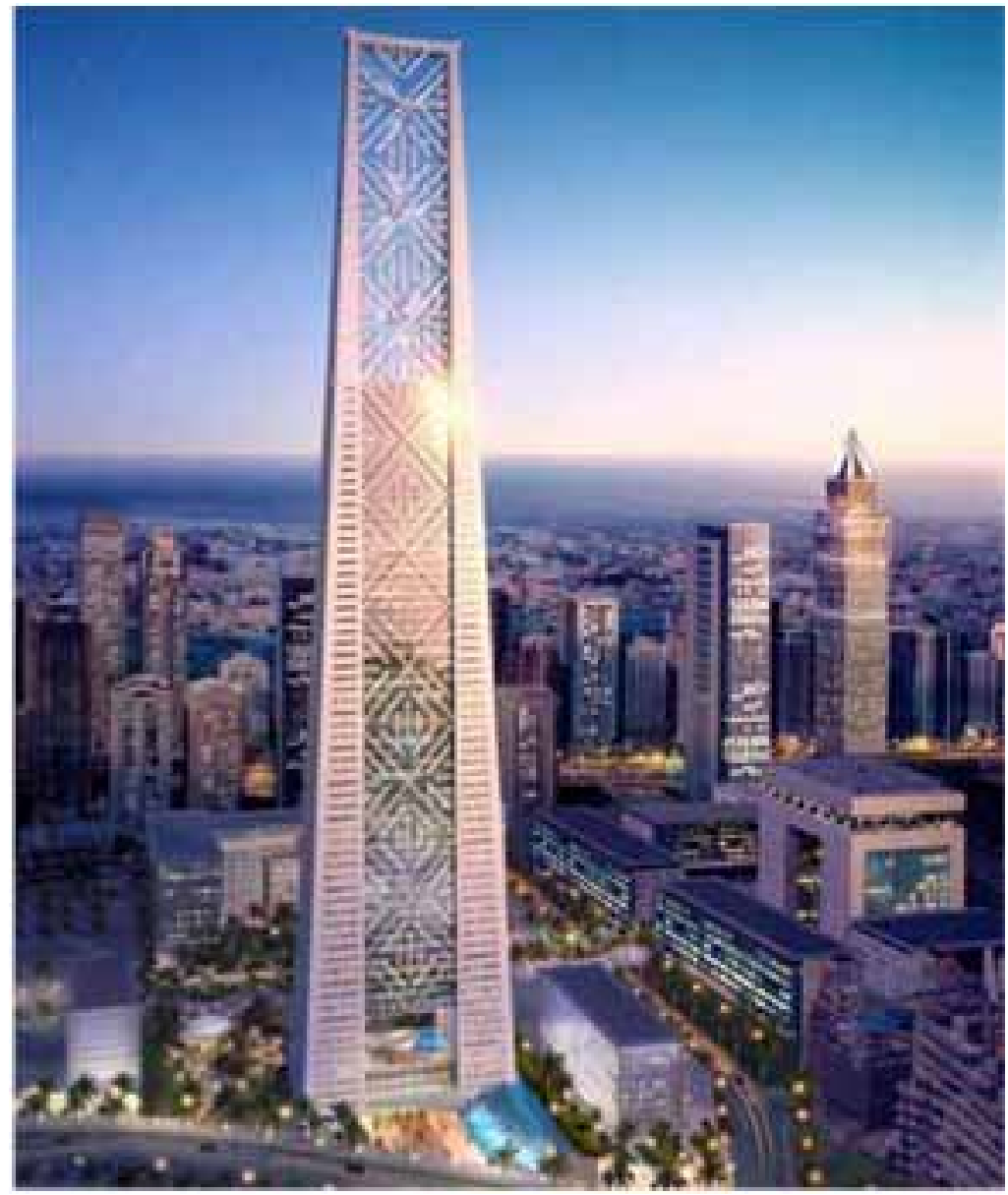

Fig. (11). The lighthouse in Dubai is a 400m high; 66-storey commercial office tower; three 29m diameter, $225 \mathrm{KV}$ wind turbines; $4000 \mathrm{PV}$ spandrel panels; $84,000 \mathrm{~m} 2$ of commercial space as well as basement and podium parking, convention centres, retail, environmental visitor centre and a park connecting to the DIFC central spine.

installed to help maintain fresh air in the rooms. Lighting was also designed to meet green building guidelines.

\section{THE LIGHTHOUSE PROJECT IN DUBAI, UAE}

It's a unique low carbon commercial tower reducing the total energy consumption up to $65 \%$ and water consumption up to $40 \%$. The height and shape of The Lighthouse play pivotal roles in its goals for low energy consumption, allowing for the instillation of three enormous $225 \mathrm{kV}$ wind turbines (29 meters in diameters), and 4,000 photovoltaic pan-

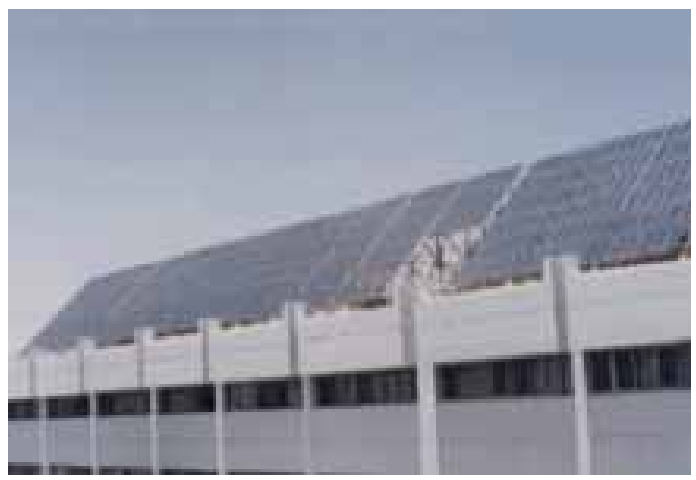

Fig. (12). Kuwait English School (Salwa): The First BIPV in the Middle East (1984). els on the south facing façade (Fig. 11). Atkins Architects hopes that The Lighthouse will serve as a working prototype for future low carbon towers in the region, promoting more sustainable developments. From our data base and research the maximum annual solar electricity received from PV panels fixed at vertical surface is $175 \mathrm{~kW} / \mathrm{h} / \mathrm{m}^{2}$ and it is for the west direction. Next comes south $\left(164 \mathrm{kWh} / \mathrm{m}^{2}\right)$ and east $\left(125 \mathrm{kWh} / \mathrm{m}^{2}\right)$ and north $89 \mathrm{kWh} / \mathrm{m}^{2}$. Therefore, the $4000 \mathrm{PV}$ panels may produce a maximum of $700000 \mathrm{kWh}$ per year (nearly $200 \mathrm{~kW}$ per day).

\section{KUWAIT ENGLISH SCHOOL (SALWA), KUWAIT}

As early as 1984, Kuwait had thought of Building Integrated Photovoltaic (a type of sustainable building). The Kuwait English School has the following features (Fig. 12):

* $\quad$ Daily Electricity Load 80 kWh.

* PV modules

* Number of batteries is 110 .

* Max. Electricity Production capacity $24.2 \mathrm{~kW}$

* Batteries Storage Capacity 200 kWh.

* Voltage 220 Volts.

* Operated 1984. 


\section{DISCUSSION}

It is most likely that issuing or coming up with legislations on renewable energy - which is highly related to sustainable building (for electrifying the buildings) - will be facing strong opposition. This is due to availability of oil and natural gas as well as opposing from public- since they now pay only 1 cent per $\mathrm{kWh}$ and will not be in their favour to raise this tariff - as among the recommendations in the above mentioned mechanisms is to put up or introduce taxes on conventional electrical energy usage. This is to limit the extensive electricity consumption, so that not further emits $\mathrm{CO}_{2}$. Also, introducing legislation on renewable energy may take long time, especially if there is no much specialist on renewable energy or intelligent or sustainable buildings design or environmentalist on green building. Therefore, we have to introduce a mechanism that is likely to be adopted in a nearby GCC country. This mechanism is the Introduction of Green Building (nearly, its an alternative name to sustainable buildings). They are buildings that have the potential to improve our lives and have long-lasting effects on the wider environment [7]. It started in USA. It was called U.S. Green Building Council

(USGBC). (http://www.usgbc.org/DisplayPage.aspx ?CategoryID=1). It is the nation's foremost coalition of leaders from every sector of the building industry working to promote buildings that are environmentally responsible, profitable and healthy places to live and work. More than 7,500 member organizations and our network of 75 regional chapters are united to advance our mission of transforming the building industry to sustainability.

There are many issues that encourage Bahrain, UAE, Kuwait and other GCC countries (Oman, Qatar and Saudi Arabia) to take part from international initiatives, mechanisms and facilities. Among these is the Clean Development Mechanism (CDM). The CDM is set by Kyoto convention which was in force in $16 \mathrm{Feb} 2005$. This CDM is valid up to the year 2012, and most likely to be further extended for 10 years. This is depends on how the world is serious about reducing $\mathrm{CO}_{2}$ emissions in our globe.

It is the chance now for investors and the government to make benefits from the CDM as the following facts do exist [8]:

- $29 \%$ of the total Arab population that are below the poverty level of 2 US\$/day.

- $41.6 \%$ of the Arab population had either no access to electricity $(21.4 \%)$, or severely undersupplied $(20.2 \%)$.

- Energy consumption varies between 0.026 to 35.7 t.o.e./ capita/ year (average of 1.228 t.o.e./ capita / year).

- Average electrification rate in the region is still $79 \%$ and goes as low as $7.7 \%$ in several countries.

Also, there are other issues that encourage Bahrain and GCC to take part in CDM and carbon trading. This will boost the PV make over for the large projects in Bahrain and GCC. These are [9]:

$a$ - The GCC countries population is nearly 28 million, which means that the total annual $\mathrm{CO}_{2}$ emission was 896 billion ton.

$\begin{array}{lccc} & \mathbf{1 9 8 0} & \mathbf{2 0 0 0} & \mathbf{2 0 0 5} \\ \text { Coal } & 24.6 & 23.6 & 25.5 \\ \text { Oil } & 42.8 & 35.4 & 34.5 \\ \text { Gas } & 17.0 & 21.9 & 21.5 \\ \text { Nuclear } & 2.6 & 5.8 & 5.4 \\ \text { Hydro } & 2.0 & 2.3 & 2.2 \\ \text { Biomass/wastes* } & 10.5 & 10.5 & 10.3 \\ \text { Other renewables } & 0.45 & 0.48 & 0.52\end{array}$

* Includes traditional and modern biomass/wastes

$b$ - The GCC strengthes are:

- $24 \%$ to $40 \%$ of World's conventional oil reserves.

- $23 \%$ of World's conventional natural gas reserves.

- High solar insolation.

c-The GCC weaknesses are:

- Arid zone, fresh water scarcity \& limited food production capacity in era of climatic warming.

- Strong social, political, \& economic adjustment challenges.

d-The Primary Energy Use per capita in 2004 (Million Btu)

$\begin{array}{llll}\text { USA } & 342 & \text { Bahrain } & 615 \\ \text { Canada } & 418 & \text { Iran } & 96 \\ \text { Argentina } & 202 & \text { Kuwait } & 470 \\ \text { Brazil } & 50 & \text { Oman } & 131 \\ \text { Venezuela } & 115 & \text { Qatar } & 850 \\ \text { France } & 186 & \text { Saudi Arabia } & 240 \\ \text { Germany } & 178 & \text { UAE } & 935 \\ \text { Norway } & 424 & \text { Algeria } & 39 \\ \text { Spain } & 160 & \text { China } & 50 \\ \text { UK } & 159 & \text { India } & 15\end{array}$

e-The Oil use per capita in 2005 (b/d)

\begin{tabular}{lll} 
Bahrain & \multicolumn{2}{c}{0.45} \\
Kuwait & 0.10 & \\
Oman & 0.02 & \\
Qatar & 0.12 & \\
Saudi Arabia & & 0.08 \\
UAE & 0.08 &
\end{tabular}

f- The Electricity Consumption per capita in 2005 (GWh)

$\begin{array}{lr}\text { Bahrain } & 10,504 \\ \text { Egypt } & 1,115 \\ \text { Jordan } & 1,445 \\ \text { Kuwait } & 13,673 \\ \text { Oman } & 3,150 \\ \text { Qatar } & 18,500 \\ \text { Saudi Arabia } & 6,074 \\ \text { UAE } & 11,872\end{array}$

g- Carbon Dioxide Emissions per capita in 2004 (World ranking) - Source: US EIA 
1. Gibraltar

2. US Virgin Islands

3. UAE

4. Netherlands Antilles

5. Qatar

6. Bahrain

7. Kuwait

8. Trinidad \& Tobago

9. Singapore

10. Luxembourg

11. USA

12. Australia

13. Canada

14. Netherlands

19. Saudi Arabia

\section{k- The Renewable Energy Options for GCC Member Coun-} tries.

- Due to climatic conditions and latitude, only solar in its various forms offers substantial opportunities:

- Passive solar (building design \& materials)

- Concentrating Solar Power

- Solar panels (especially thin film)

- Wind power may offer some limited opportunities but again traditional wind towers offer significant benefits.

- Ocean, biomass, hydro and geothermal is not expected to offer significant opportunities.

- There may be opportunities for GCC member countries with significant oil \& gas export revenues to acquire/sponsor solar energy technologies (for power, heat and saline water treatment) and advances in transmission and storage technologies/efficiency.

We also believe that the following mechanisms will accelerate the construction of sustainable buildings or green buildings in Bahrain. These are:

\section{a- Need of Establishing Green Building Council in GCC countries}

The core purpose of The U.S. Green Building Council's is to transform the way buildings and communities are designed, built and operated, enabling an environmentally and socially responsible, healthy, and prosperous environment that improves the quality of life. USGBC leads one to make decisions as seriously as the decisions themselves.

Currently, there is The World Green Building Council. It is made up of members of Green Building Councils from around the world. Now there is Green Building Design Council in USA, Australia, India, China, Mexico, New Zealand and United Arab Emirates. Bahrain and other GCC countries can join such council since UAE had made so. We are now working hard with the Emirates Green Building Council to make use of there experience.

On the $2^{\text {nd }}$ of July 2006 the Emirates Green Building Council (Emirates GBC) was officially establishment in
UAE, which is a member state of Gulf Cooperation Council (GCC) countries.

Such a council can be established in Bahrain and the GCC countries - even should be in all Asian Countries. GBC has the goal of advancing Green Building principles for protecting the environment and ensuring sustainability. Its vision is primarily centered on achieving the highest level of Sustainable Built-environment through the promotion of high-performance Green Buildings and environmentally friendly technologies.

The GBC mission goal statement includes [10]:

- Provide awareness on the importance of sustainable management of the environment.

- Foster collaboration between all sectors of property and construction industry, government, academic institutions and other stakeholders to transform the built-environment to be a Green Building model.

- $\quad$ Provide a venue for vibrant participation of all concerned to develop Green Building solutions adapted to suit the culture and architecture.

- Establish a Green Building Model that encompassing standards and best practices appropriate for the environment for the region.

- Create a vehicle for education.

The Founding Member Board of the Council can comprise of many founders and renowned organizations covering different sector of the building industry including:

- Developers

- Civil bodies (NGO)

- Energy Companies

- Consultants

- Contractors

- Landscape contractors

- Manufacturers \& Suppliers

- Facility \& Hospitality Management

- Energy Management Services

- Water Consultants

The global environmental problems are increasingly threatening water and air quality and the ecosystems which inhabitants depend on in their daily life. The construction industry ought to be transformed from a conventional to a Sustainable or High-performance Green Building that produce fewer pollutants and consequently protects the environment.

\section{b- Establish Green Building Certification, i.e. Leadership in Energy and Environmental Design (LEED)}

LEED is a voluntary standard for assessing building performance and meeting sustainability goals. It's based on industry standards developed by the United States Green Building Council States and emphasizes state of the art strategies for sustainable site development, water savings, 
energy efficiency, materials selection and indoor environmental quality.

Applying the concept has proved to enhance the asset value and profitability of the building. A building that satisfies LEED $^{\mathrm{TM}}$ certification requirements positively impacts labor productivity, retail sales, hotel resident comfort and manufacturing quality and output. Moreover, comfortable spaces tend to keep tenants in their occupancies for longer periods.

LEED provides a complete framework for assessing building performance and meeting sustainability goals. Based on well-founded scientific standards, LEED emphasizes state of the art strategies for sustainable site development, water savings, energy efficiency, materials selection and indoor environmental quality.

LEED certification programme has been developed by the USGBC (US Green Building Council), which is a voluntary, consensus-based national standard for developing high performance, sustainable buildings. LEED provides a framework for assessing building performance and meeting sustainability goals and recognizes it through its rating system, which includes a certified (26-32 points), silver (33-38 points), gold (39-41 points) and platinum (52 or more points). Pacific Controls earned 55 points.

To achieve a green building certification, there were a number of prerequisites and credits required to be documented and achieved. Some of these that can be found in our building include innovative wastewater recycling technologies, water use reduction through the installation of water conservation fixtures, water efficient landscaping designs, optimising energy performance, CFC reduction in HVAC, $\mathrm{CO}_{2}$ monitoring, low emitting building and finishing materials, thermal comfort control, IAQ (indoor air quality) management planning during construction and before occupancy and several other features.

\section{c- Establish Policies for Sustainable Buildings}

The above sections has dealt with policies recommended by the International Solar Energy Society [11,12], as general package for both worldwide and for developed countries, to accelerate the use of renewable energy (since BIPV and BIWT are dependent on renewable energy; solar and wind energy). It also had added further tips to enhance this acceleration. Also, we have set the policies that will mainly encourage the dissemination of BIPV (green buildings). This section can also contribute for accelerating the use of constructing BIPV under the concept of sustainable building. This may be more effective as people and government becomes more concern with environment, especially that media, now days, is highlighting on this issue in the front covers. Time magazine had produced an issue on "The Global Warming Survival Guide". The magazine, in its Aril issue 2007, had sought the opinion of dedicated thinkers to end up with 51 things one should do a make a difference in the global warming phenomena. Among these is number 6 " Ditch the McMansion". It deals with sustainable buildings. Also number 7 " Build a skyscraper" which also related with sustainable building construction and management. Item 19 "Buy green power at home or away" is dealt with what we had discussed earlier in the above section (Feed-In Mecha- nism). Item 33 "Rearrange the heavens and the Earth" was also related with dealing with solar electricity from space to buildings. Item 49 " Set a higher standard" is what are we discussing in this section as policies. Furthermore, item 50 " Be aggressive about passive" is a sustainable building matter. Most interesting is item 43 " Move to London's new green zone" which highlights on building 233 homes in London that will be hooked up with solar panels and wind. This will reduce the $\mathrm{CO}_{2}$ emission in London as homes in London account for $44 \%$ of the city's $\mathrm{CO}_{2}$ emissions. This indicates how building construction and management is important to combat global warming.

The Organization for Economic Co-Operation and Development [2] focuses on three environmental objectives closely related to the building sector: reduction of $\mathrm{CO}_{2}$ emissions, minimization of construction and demolition waste and prevention of indoor air pollution. These policies are important since it was set by 22 member countries (UK, USA, Germany, Japan are among them). The importance of policy design in this area has been illustrated by the previous chapters of this report. The building sector has, directly and indirectly, great impact on these environmental issues, and government intervention in the sector should have great potential to contribute to the achievement of environmental objectives. On the other hand, the building sector has various unique characteristics that create barriers to improving environmental performance. Consequently, discussions on policy design in other sectors are often not applicable to the building sector, and policy makers are required to give special consideration to how environmental policies for the building sector might be best designed.

OECD had provided guidance for policy design, both theoretical and empirical studies. This policy instruments were analyzed. Some theoretical assumptions were found to be consistent with empirical evidence, and some others contradicted empirical findings. The effectiveness of policy instruments depends highly on the decisions that policy makers take at every stage of designing and implementing environmental policies. Such Policies can be made use of in the GCC.

\section{d-UNEP's Sustainable Building and Construction Initia- tive (SBCI)}

This is probably the most suitable approach for introducing and strengthening the sustainable building in Bahrain. It contains a very practical steps and realistic one. It allows bringing together stakeholders from all phases of building's lifespan, such as material manufacturers, architects, estate developers, construction companies, maintenance and service companies as well as local authorities. It also provides a common platform for these stakeholders to work together with United Nations Environment Programme (UNEP) to identify opportunities for change towards sustainability, and develop mechanism for realizing those opportunities. It contains members from all over the world. Members will take active part in developing and defining the initiative's work programme according to their Bahrain. Local companies in Bahrain in the field of construction should join immediately. The fees is negligible compared to benefit gained $(\$ 30000$ for multinational company $\$ 15000$ for national company and only 5000 for others. The full Information note on SBCI 
Worldwide investment in the building and construction sector

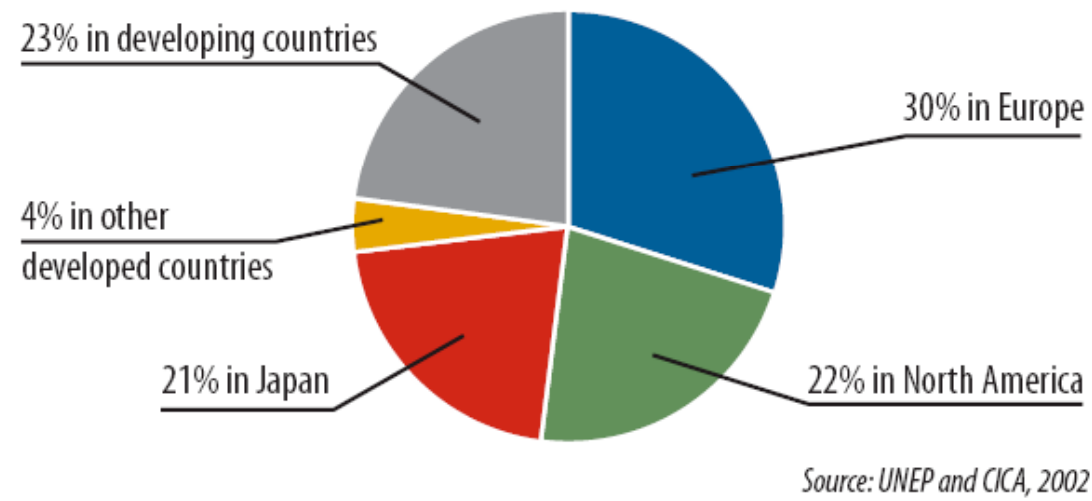

Fig. (13). Worlwide investment in the building and construction sector.

was published in early 2006 [13] - after been launched in Paris on $21^{\text {st }}$ February 2006.

It is a new international effort to "green" the multi-billion dollar building and construction sector was launched here today with some of the biggest names in the business. The Construction giants Lafarge, Skanska and Arcelor are among the founding members of the SBCI, which aims to promote environmental friendly practices across this vast industry.

The Building and Construction sector employs over 100 million people worldwide and contributes approximately $10 \%$ of global Gross Domestic Product (GDP), also it has a serious impact on many of the world's most pressing environmental problems like climate change, waste generation and depletion of our natural resources. One key area of concern is the large share of energy use, with associated greenhouse gas emissions, that the built environment accounts for. In some countries the built environment is responsible for up to $40 \%$ of total energy use (Figs. 13 and 14).

The overall objective of the SBCI (http://www. unep.fr/pc/) is to achieve worldwide adoption of sustainable building and construction practices that can help deal with such problems. It also aimed to produce reports on key is- sues like the impact of energy efficiency in the built environment on climate change, and a manual linked to reconstruction of buildings in the wake of natural disasters like the Indian Ocean Tsunami. A key feature of the SBCI will be to bring recommendations to implementation, including the development of pilot projects.

It is hoped that the work of the SBCI will help ensure buildings are routinely designed, constructed and maintained from an environmentally sustainable point of view over their entire life span, taking into account what is called the "lifecycle approach". Other goals are that increasingly legislation and building standards include sustainability considerations and requirements. And, that policies and incentives provided by the governments support sustainable building and construction practices.

The SBCI has been set-up as a neutral and worldwide platform, in partnership with international leading companies and others working in this area. As such it will be able to provide direct input to other initiatives, governments and global bodies making recommendations and decisions affecting sustainable development in this sector. It aims to complement on-going efforts in various countries that are de-

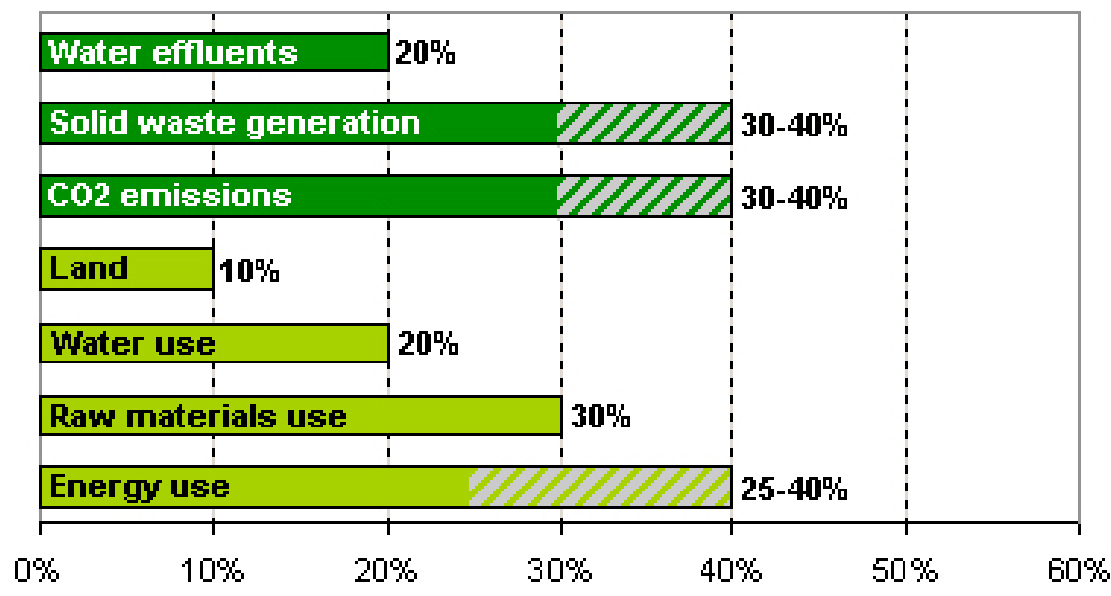

Fig. (14). Share of the built environment in resource use and in pollution emission. (refer to EarthTrends, 2007 using data from UNEP SBCI,2006 on http://earthtrends.wri.org/updates/node/232). 


\section{Functional structure of the Initiative}
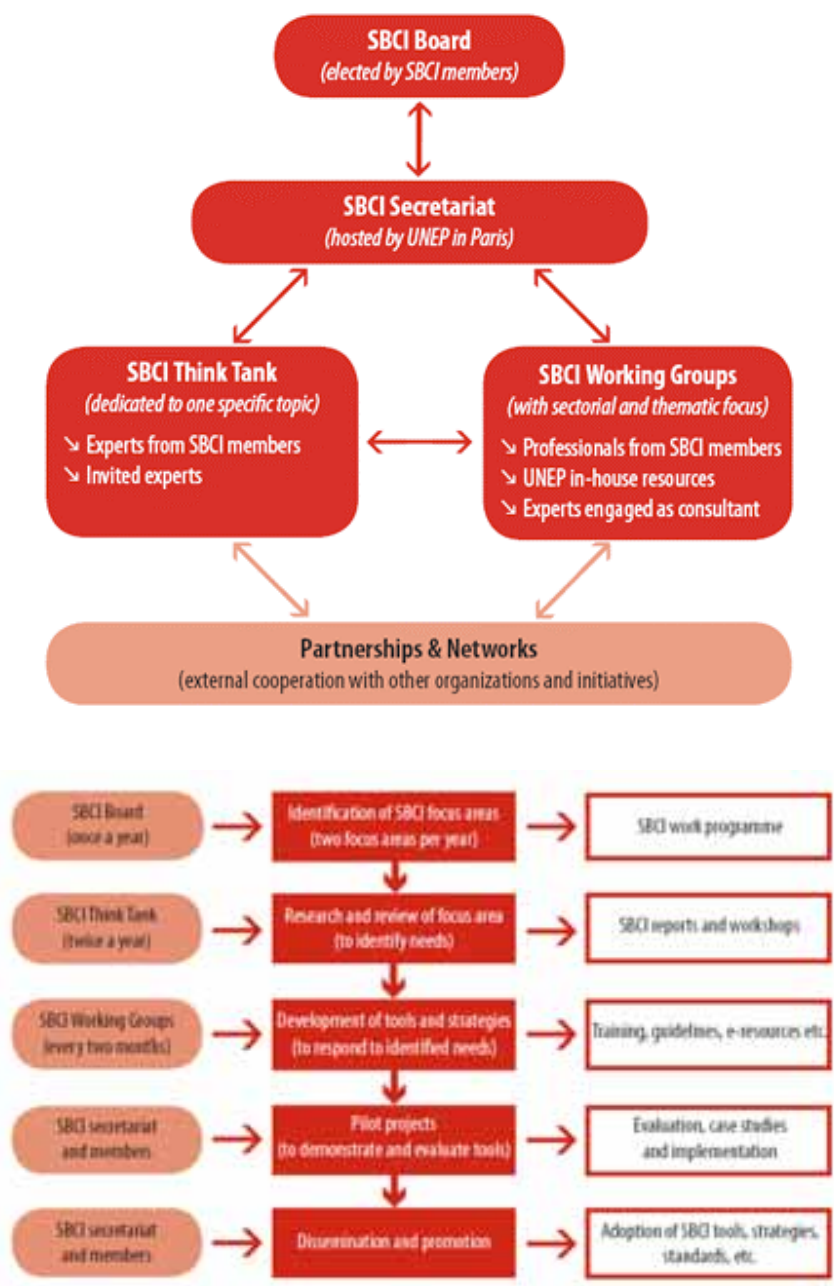

Fig. (15). The organization of SBCI regular work programme.

signed to assess and compare the environmental performance of buildings such as LEED in the United States, BREEAM in the UK and HQE in France.
Other partnerships will include the responsible investment working group under the UNEP Finance Initiative. The SBCI will also look to build on the existing work of UNEP DTIE's Ozon Action programme in the refrigeration and air conditioning sector, which is tackling the problem of energy consumption in existing buildings.

The organization of SBCI regular work programme is illustrated in Fig. 15. It starts with Identification of SBCI focus areas (two focus area per year), followed by research and review of focus area(to identify needs), development of tools and strategies ( to respond to identified needs), pilot projects ( to demonstrate and evaluate tools) and finally dissemination and promotion.

In fact, joining the SBIC will lead to several benefits such as:

1- Taking an active role in shaping the market of sustainable building and construction.

2- Creating inputs to international and national strategies for meeting global challenges.

3- Contributing to the way the issues linked to the building and construction sector will be addressed in the international debates on climate change.

4- Cross-cutting access to cooperation with other key players engaged in sustainable development.

5- Accessing the latest tools, strategies and news on sustainable building and construction worldwide.

6- Acquiring priority access to pilot and demonstrate projects and partnerships worldwide.

7- Conducting your sustainability work in association with a global initiative.

The SBCI members will take an active part in developing and defining the initiative's work programme according to their interest. The SBCI provides a common platform for these stakeholders to work together with UNEP to identify opportunities for change towards sustainability, and develop mechanisms for realizing those opportunities. It will not replace or compete with the numerous other initiatives aiming at researching sustainability in the building and construction sector but will seek to complement them by the translating their findings into on-the -ground action through pilot projects. Fig. 16 summarize the mechanism.

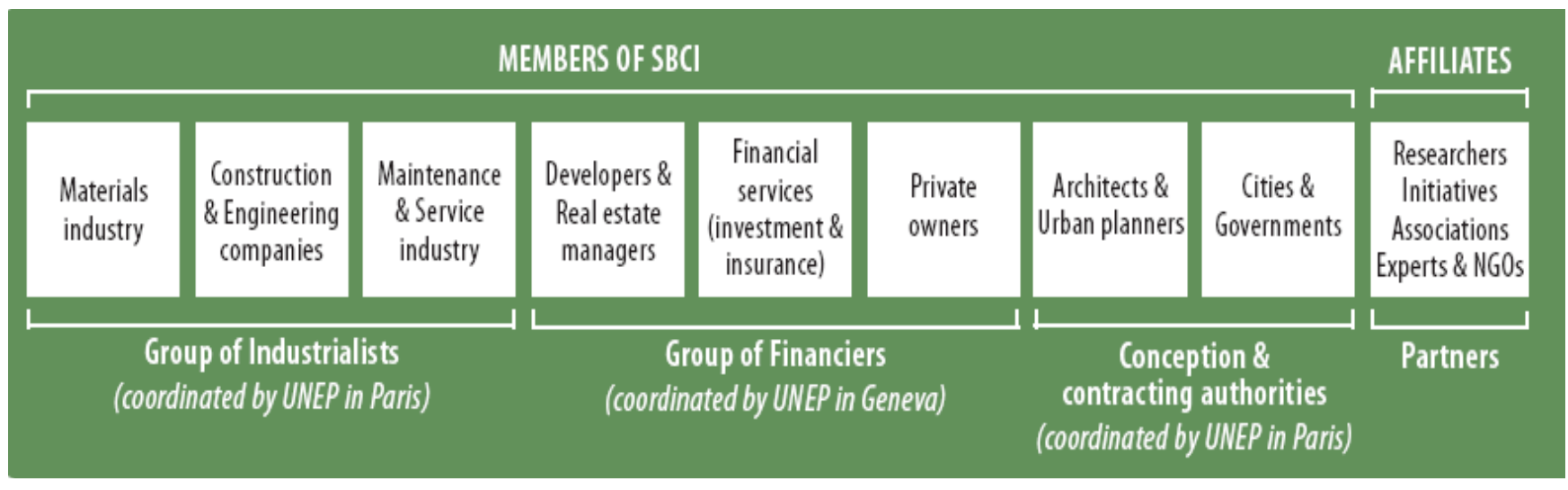

Fig. (16). The mechanism that shows the role of members of SBCI. 


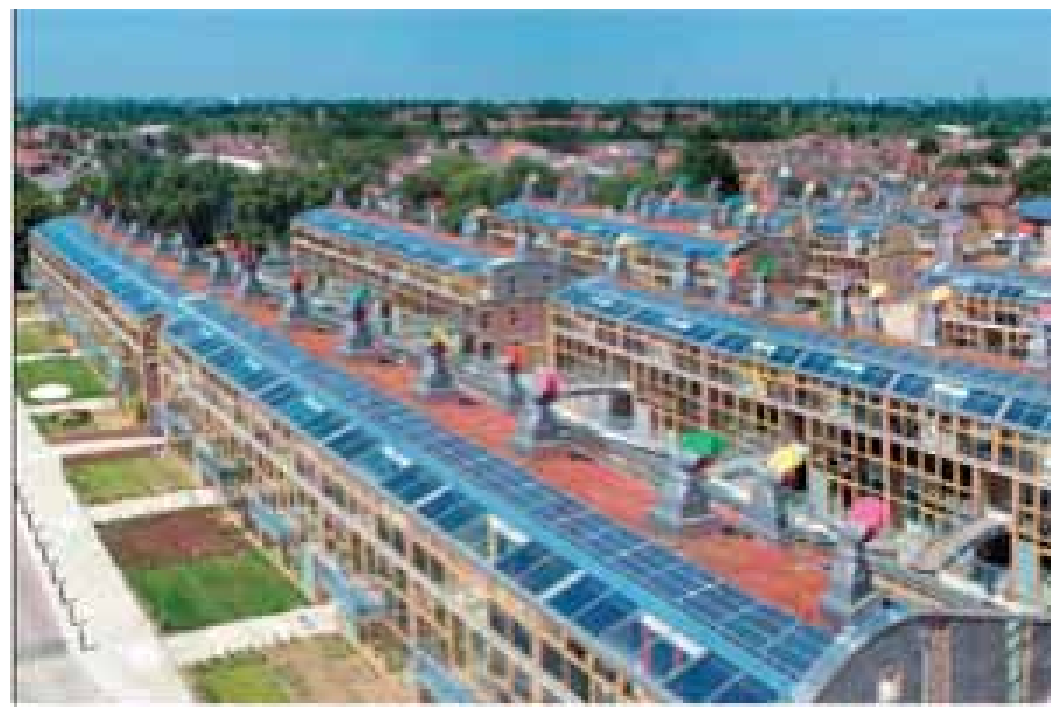

Fig. (17). The Bedzed, zero energy (gallerid apartments in Great Britain);a pilot project integrating sustainable technologies.

SBCI is expected to boost sustainable building design. The Bedzed, zero energy (gallerid apartments in Great Britain), Fig 17, developed by Bill Dunster Architics as a pilot project integrating sustainable technologies should stand a good example of how SBCI accelerate its execution. Probably the Almoayyed tower and Bahrain International circuit be among such supported projects at international level.

\section{e-Needs of Investors in Making -Over to BIPV or BIWT or Sustainable Buildings or Green Buildings}

We had made several meetings with owners and investors in the building and construction sector. This was during our MSc studies [14] and recently. If there are several existing building construction that are not sustainable and can be made-over as sustainable. Investors in Bahrain, UAE and Kuwait are interested in switching to sustainable but several hurdles are facing them. These are:

1-The cost of makeover to a sustainable building: The cost of make -over or constructing a sustainable building is relatively expensive. For example, with the current prices of Electricity tariff ( 3 fils per $\mathrm{kWh}$ or nearly 0.9 cent per $\mathrm{kWh}$ ) the return or revenue will be very low. The payback, which is the ratio of the cost of PV make-over to the cost of amount of solar electricity obtained (for a large tower consuming 2 MW) will be only after 900 years! In Europe (Germany and UK) the investors are somehow guaranteeing a payback within 10 years, especially when taking into account the support of the governments. If the prices of $\mathrm{kWh}$ of the electricity unit in Bahrain are made equal to UK - which is nearly 40 fils (which is 13 folds) - then the payback will be 70 years instead of 900 years. If batteries are avoided (saving $£ 0.5 \mathrm{~m}$ ), i.e. the PV's are directly linked to the national electricity grid in summer months if the solar panels with the installation cost is reduced (which can be made by operating a PV panels manufacturing with joint ventures with large companies of PV's) then the payback will be 357 years with our current electricity tariff - and to 29 years with tariff similar to UK. One should note that the solar gain in Bahrain, UAE and Kuwait is very high (nearly twice of UK). This will lead to lower needed budget for batteries as well less number of PV panels, compared to a similar building in Europe.

2-Lack of Incentives: There is no incentive at all in Bahrain for constructing any BIPV building or sustainable building. This is neither from the government or public. The German Renewable Energy Act mandates that for groundmounted PV will drop from 45 cents per kilowatt-hour in 2004 to 25 cents per kilowatt-hour in 2013. BIPV receives extra compensation, and an extra 5 cents is paid for panels attached to facades (Morris 2007). Such panels take no additional space and provide maximum power around noon, when spot market prices are highest and sometimes even exceed the rates for PV. This shows how government supports BIPV, i.e. the PV on facades received more support than installing PV on the roof top of a building. The tenants will not appreciate in occupying flats or offices in a sustainable building. If the government introduces a legislation that all commercial buildings should be a green building (at least a silver green building like Florida State in USA) then such BIPV will be winners. Government should make a system of buying any electricity unit from solar and wind from the investor with a handsome rate that enables the investor (having a large tower consuming $2 \mathrm{MW}$ ) to have a payback of no more than 10 years. For example, if the government buy the solar electricity from the investors by twice the ordinary rate then the payback will be 14.5 years instead of 29 years (if UK tariff is used) and to 9.6 years if the solar electricity is purchased at a rate of 3 times the normal rate (like Germany).

In fact, the incentives can not be provided widely open. It will cost the government a fortune. The typical solution is that the government provide higher incentives for those who start first the BIPV or sustainable Buildings projects. Fewer incentives shall be provided for further projects. The incentives will be small if the prices of PV, and other accessories, as the construction prices will automatically go down because such BIPV will be popular and job as usual. In Germany, the government had made similar system. To a certain extent UK had made the same but indirectly. They put a fund 
of $£ 20$ million annually for house - not more than $2 \mathrm{~kW}$ - to be made BIPV or BIWT. Those who apply first receive $50 \%$ payback of the cost prior to others.

3-Need of International Support: If the owner or the investor obtained the so-called Certificates of Emission Reduction (CER) or the receive fund from $\mathrm{CO}_{2}$ fund - resulted from Kyoto agreement (which comes to force on $16 \mathrm{Feb}$ 2005)- under Clean Mechanism Development (CMD) then the investors will receive $€ 10$ per ton of saved $\mathrm{CO}_{2}$. In the case of a $2 \mathrm{MW}$ power consumption tower, the annual saving of $\mathrm{CO}_{2}$ will be 3000 ton. This will qualify the investor to receive an annual financial income of a $€ 30000$ (BD 15 000). This will reduce the payback period to nearly 9.0 years (BD 1.45 million / [1 $290000 \mathrm{kWh} \times$ BD 0.12].

4-Consideration of Tenants: Investors in BIPV show concern of the tenants comfort during the stage of renovation or executing the installation of PV panels on the façade. Tenants, in fact hate hearing noise and disturbance. This may be overcome if tenants are informed and made aware that there electricity will be guaranteed from blackout. In fact, tenants may be interactive in a way that they may be willing to pay more rent as a contribution toward saving Bahrain's environment and the globe. At this stage special privileged should me offered to those tenants by the government and the public.

5-Establishing an Energy Code for a building or energy rating a building; Investors felt that without no restrictions on energy consumption and energy demand for large commercial construction projects it will be difficult for them to put more money and fund on their projects (more cost) while others can gain more income from their projects even though their building is not energy efficient or energy saving. They insisted that for BIPV to be encouraged their must be a certain limit for energy consumption per $\mathrm{m}^{2}$ otherwise the cost of electricity should much higher than the standard probably by 20 folds or not. Also, the scores of LEED (leadership Engineering and Environmental Designs for a building (Platinum, Gold and Silver) must be adopted. In certain states in USA the governmental buildings must have silver point or silver certificate. In fact, we had started a conduct with the founder of Emirates Green Building Council (a council among 9 at international level) to write a proposal to the Minster of Works and Housing. The proposal now is at the Minister's attention. Also, if the parliament put in force a law that any commercial investment or governmental building should have at least $10 \%$ (or less) of its electricity from a renewable energy source Solar or wind then BIPV or BIWT will be flourish and will have less $\mathrm{CO}_{2}$ per capita in Bahrain, UAE and Kuwait (and other GCC countries) within short period.

6-Need of Joint Venture Projects and International Cooperation: The investors and contractors have no doubt that they can conduct BIPV or Sustainable building designs relaying on local identity. However, they all agree that such method will be extremely expensive and probably time consuming. Joint Venture Projects and International Cooperation will reflect positively on BIPV projects with a much better work quality and state of art technology. This will offer lower cost for BIPV. It's a win -win situation. This is because a success of such project will encourage other investors to think of sustainable building designs.
In order to be successful in conducting sustainable buildings projects it is necessary to create the conditions and incentives that would encourage stakeholders in the sector to actively pursue such projects. This can be made from governmental policies, or economic incentives, rating systems [silver, gold and platinum green building in LEED (USA) or BREEAM (England) or HQE (France)] and coordination with key partners, such as the financing sector or CER (Certificate of Emission Reduction) traders or CDM system. A prove of such successful approach is what had been achieved recently in Jordon. The Ministry of Environment at Jordon had signed a contract with central electricity company (conducting a tourist resort in Al Aqaba integrated with Concentrator Solar Power ,CSP) that the company is obliged to pay $15 \%$ of its revenue from selling CERs of $\mathrm{CO}_{2}$ for 5 years . This project is expected to sell CERs worth $\$ 70$ million (Al Beaa and Al Tanmeya magazine, July issue, 2007, page 74). Three companies had submitted their bidding to buy the CERs from the investor (who received a lot of facilities and support from the Ministry of Environment). An Irish Company (Eco- Securities) had won the bidding at a rate of $€ 7.2$ (\$ 9.6) per ton of saved $\mathrm{CO}_{2}$. Such system can be adopted for making-over to a sustainable building construction.

\section{CONCLUSION}

In order to be successful in conducting sustainable buildings projects it is necessary to create the conditions and incentives that would encourage stakeholders in the sector to actively pursue such projects. This can be made from governmental policies, or economic incentives, rating systems [silver, gold and platinum green building in LEED (USA) or BREEAM (England) or HQE (France)] and coordination with key partners, such as the financing sector or CER (Certificate of Emission Reduction) traders or CDM system.

Several strategies have to be employed for the long term cost reduction of BIPV namely (a) Establishment of BIPV Information Services, Awareness and Capacity Building Programs (b) Development of BIPV Market Enhancement and Infrastructure development (c) Improvement of Policy and Financial Frameworks Supportive for BIPV Market Sustainability and (d) Establishment of competitive local BIPV manufacturing industries and R\&D. Moreover, these strategies should be addressed in an integrated manner.

One advantage of UNEP's SBCI is that it initiated work on pilot projects in the focus area and then identified additional funding sources to support this specific activity. This is done after selecting the focus area by SBCI think tank.

In fact, selecting the suitable mechanism, policy or strategy and in working beside UNEP's Building and Construction Initiative the vicious circle of blame, i.e. the investors in Bahrain like to fund sustainable buildings but there is no demand for them, the constructors can build sustainable buildings but the developers do not ask them, the developers would ask for sustainable buildings but the investors won't pay for them.

\section{ACKNOWLEDGEMENT}

The author would like to thank Professor R Flanagan, University of Reading, for his careful supervision to this work and to W E Alnaser, professor of applied physics at the University of Bahrain and chairman of Arab section, ISES 
(Germany) for his assistance in doing solar energy sizing. Thanks also for the Royal Court, Kingdom of Bahrain.

\section{REFERENCES}

[1] F.S. Smith, Architecture in a Climate of a Change: A guide to sustainable design, UK; Architectural Press, An imprint of Butterworth-Heinemann, 2001.

[2] Organization for Economic Co-operation and Environment, OECE, Environmentally Sustainable Buildings: Challenges and Policies.Paris, France; OECD publication, 2003.

[3] J. Benemann, O. Chehab, and N. Schaar-Gabriel (2001)," Building -Integrated PV Modules", Solar Energy Materials and Solar Cells, vol. 67, Issue 1-4, pp. 345-359, 2001.

[4] M.M. Aboulnaga, and Y.H. Elsheshtawy, (2001)"'Environmental Sustainability Assessment of Buildings in Hot Climates: The Case of the UAE",Renewable Energy, vol. 24, no. 3-4, pp. 553-63.

[5] M.M. Aboulnaga “ Toward Green Buildings: Glass as a Building Element - The Use and Misuse in The Gulf Region, Renewable Energy “, vol. 31, pp. 631-653, 2006.

[6] R Smith, and S. Killa, “ Atkins Puts Smart Design into BWTC “, Gulf Construction, pp. 54-61, January 2006.

[7] R. McMullan, Environmental Science in Building, 5th Edition, China, Palgrave, 2002.
[8] A. M. Al Hadad, Renewable Energy and Clean Development Mechanism (CDM), Seminar on Renewable Energy for Policy and decision makers, 28 May 2007, College of Science, University of Bahrain, 2007.

[9] M. Jefferson, Energy for Sustainable Development: Global Context and Rational Options for the GCC, $2^{\text {nd }}$ Seminar on Potential of Alternative Energy in the GCC, 24-25 April 2007, Arabian Gulf University, Kingdom of Bahrain. 2007.

[10] M. Abulnaga Green Buildings are the Way Forward for the Region: The UAE Experience, $2^{\text {nd }}$ Seminar on Potential of Alternative Energy in the GCC, 24-25 April 2007, Arabian Gulf University, Kingdom of Bahrain, 2007.

[11] ISES \& W. Aitken, Transitioning to a Renewable Energy FutureWhite Paper, Freiburg, Germany, 2003.

[12] ISES \& D. Holm, Renewable Energy Future For The Developing World, -White Paper, Freiburg, Germany. 2005.

[13] UNEP, Sustainable Building Construction Initiative (Brochure): http://www.unep.fr/pc/pc/SBCI/SBCI_2006_InformationNote.pdf, 2006.

[14] N.W. Alnaser, and R. Flanagan "The Need of Sustainable Buildings Construction in the Kingdom of Bahrain", Building and Environment, vol. 42, pp. 495-506, 2007. 